\title{
PERLINDUNGAN HAM (HAK ASASI MANUSIA) DALAM KONSEPSI NEGARA HUKUM
}

\author{
Rabi Yati \\ Email: 2010128120009@ mhs.ulm.ac.id \\ Program Studi Pendidikan IPS Fakultas Keguruan dan Ilmu Pendidikan \\ Universitas Lambung Mangkurat \\ Banjarmasin
}

\begin{abstract}
Abstrak
Hak asasi manusia (HAM) adalah seperangkat hak kodrati yang bersifat universal, dimiliki oleh setaiap manusia dan telah melekat pada diri seseorang semenjak ia lahir sebagai pemberian langsung atau anugerah dari Tuhan yang Maha Esa. Hak asasi manusia wajib untuk dijunjung tinggi oleh setiap orang, negara, pemerintah maupun hukum, terutama dalam konteks negara hukum, yang mana telah menjadi ciri dari negara hukum untuk menjamin perlindunagn hak asasi manusia yang telah tercantum di dalam hukum konstitusi maupun hukum nasional setiap negara hukum. Karena pada dasarnya dalam negara hukum itu mementingkan adanya suatu kesetaraan dan kesamaan derajat antar sesamanya di mata hukum tanpa adanya pengecualian. Oleh karena itu, penulisan artikel ini ditujukan untuk melihat dan memperdalam mengenai fenomena-fenomena perlindungan hak asasi manusia dalam konsepsi yang mengarah kepada negara hukum, terutama di Indonesia yang merupakan salah satu negara hukum di dunia. Artikel ini dibuat dengan menggunakan metode deskriptif dan pengumpulan data melalui studi kepustakaan sehingga diperoleh hasil dan kesimpulan dari rumusan masalah tersebut.
\end{abstract}

Kata Kunci: HAM, Negara Hukum dan Hukum.

\section{PENDAHULUAN}

Negara Hukum merupakan negara yang memiliki asas negara hukum dimana segala periaku dan tindakan warga negaranya diatur di dalam perundang-undangan yang telah disusun oleh pemerintah. Di daam konsep negara hukum, pemerintah dalam penyelenggaraan negaranya menempatkan gagasan perlindungan hak asasi manusia sebagai salah satu unsur penting yang harus dijalankan. Dengan mempertimbangkan pentingnya perlindungan hak asasi manusia tersebut, maka konstitusi negara harus memuat pengaturan hak asasi manusia agar ada jaminan negara terhadap hak-hak warga negaranya. Sebagai negara hukum tentunya memiliki kewajiban utama yang harus di laksanakan yakni berkewajiban dalam hal melindungi hak-hak warga negaranya dengan cara yang tegas dan tidak memihak kepada suatu kelompok tertentu, yang dicantumkan ke dalam hukum konstitusi maupun hukum nasional. 
HAM (Hak Asasi Manusia) merupakan seperangkat hak kodrati yang dimiliki oleh setaiap manusia yang telah ada sejak dari lahir sebagai pemberian mutlak atau anugerah dari Tuhan Yang Maha Esa. Hak asasi manusia wajib dijunjung tinggi oleh semua orang, yang mana hak ini sifatnya universal dan tidak hanya dimiliki oleh orang tertentu, melainkan oleh semua orang, dan seluruh warga negara wajib untuk menghormati dan hak sesamanya. Sebagai negara hukum tentunya akan menjunjung tinggi hak yang dimiliki warga negaranya dengan penetapan perundang-undangan mengenai perlindungan hak warga negara yang menjadi kewajiban bagi negara terutama pada negara hukum yang tentunya perlindungan hak dan pelaksanaan kewajiban tercantumkan di dalam konstitusi dan hukum nasional tertulis negara yang akan melindungi hak warga negarannya. Penetapan perundang-undangan sesuai dengan hukum konnstitusi dan nasional ini tentunya bertujuan untuk menjaga setiap hak warga negara untuk menghindari perlakuan sewenang wenang baik dari oknum pemerintah atau pemimpin maupun antar sesama warga negara degan konsepsi hukum yang mengikat warga negaranya.

Dalam perkembangannya, HAM di berbagai negara di dunia telah diterima dengan baik secara universal, dimana HAM ini telah menjadi pedoman baik dalam hal moral, politik, maupun sebagai penentu kerangka hukum. Penetapan hukum yang mengatur perlindungan hak asasi manusia bagi warga negaranya menunjukkan bahwa negara menjunjung tinggi posisi HAM, yang mana hal ini telah menjadi kewajiban negara juga untuk melindungi hak setiap warga negaranya. Terjaminnya perlindungan HAM bagi warga negaranya yang telah diatur dalam hukum konstitusional maupun nasional merupakan salah satu ciri utama sebuah negara hukum, dimana di dalam negara hukum juga mementingkan suatu kesetaraan dan kesamaan derajat antar sesamanya tanpa adanya pengecualian.

Oleh karena itu, penulisan artikel ini ditujukan untuk melihat dan memperdalam fenomena-fenomena perlindungan hak asasi manusia dalam konsepsi yang mengarah kepada negara hukum, terutama di Indonesia yang merupakan salah satu negara hukum di dunia yang memiliki hukum yang menjunjunng tinggi perlindungan hak-hak warga negaranya, yang mana hal ini telah tercantum dalam pengaturan hukum baik dalam hukum konstusi negara yang berupa Undang-Undang Dasar, maupun hukum nasional. Pengkajiannya juga memfokuskan mengenai bagaimana upaya negara dalam memenuhi perlindungan hak asasi manusia dalam negara yang berlandaskan hukum.

\section{METODE PENELITIAN}


Artikel ini menggunakan metode desktriptif, yang mana metode ini ditujukkan untuk mengetahui dan mengumpulkan data-data penelitian mengenai hak asasi manusia melalui studi kepustakaan melalui jurnal-juran, buku, dan sumber-sumber aktual lainnya yang terpercaya dan memberikan informasi akurat mnegenai hak asasi manusia, baik dalam bentuuk definisi, konsep, fenomena dan gejala berdasarkan realitas yang ada. Yang kemudian data-data yang telah dikumpulkan tersebut disusun dan di deskripsikan sedemikian rupa hingga membentuk suatu penjelasan konsep, gagasan maupun ide mengenai perlindungan ham yang telah melekat dalam tatanan penyelenggaraan negara hukum. Sehingga terbentuklah suatu gambaran mengenai rumusan masalah dan tujuan dari penelitian ini dibuat, yakni mengetahui bagaimana upaya negara dalam memenuhi perlindungan hak asasi manusia dalam negara yang berlandaskan hukum. Dan tentunaya denga mempelajari bahan-bahan hukum primer, hukum sekunder dan hukum tersier sebagai tuntunan dan pedoman dalam menganalisis fenomena yang diteliti.

\section{KONSEP NEGARA HUKUM}

Negara hukum merupakan negara yang di dalam pelaksanaan ketata negaraannya berlandaskan kedaulatan hukum, yang telah diatur sedemikian rupa dan memiliki hukum konstitusi tertinggi, yaitu hukum yang menjadi sumber dari segala summber hukum yang ditetapkan dalam suatu negara. Dalam pengertiannya, para ahli mengememukakan pendapat negara hukum dalam konteks yang berbeda-beda. Menurut B.R. Saragih dalam negara hukum merupakan sebuah negara yang mana segala tindakan baik pemerintah maupun rakyatnya didasarkan atas hukum yang bersifat mengikat untuk mengatur atau mencegah timbulnya tindakan sewenang-wenang dari pihak pemerintah maupun dari rakyat yang dilakukan atas dasar tindakan yang mementingkan kehendaknya sendiri (Wahab et. al, 2014). Hal ini menunjukkan bahwa dalam negara hukum segala kebijakan maupun wewenang dan amanah semuanya berlandaskan atas dasar hukum, tidak ada kebijakan dan wewenag yang tanpa didasari hukum.

Dalam pengertiannya, negara hukum dapat di istilahkan sebagai The Rule Of Law, istilah ini tercetus semenjak terbitnya buku Intruduction to the study of the law of the constitution yang ditulis oleh A.V.Dicey (1885). Dimana suatu negara dapat dikatakan sebagai sebuah negara hukum apabila memenuhi unsur-unsur maupun syarat-syarat tertentu yang mesti dipenuhi oleh suatu negara. Yang mana unsur-unsur negara hukum tersebut menurut Dicey berdasarkan the rule of law ada tiga unsur yang mesti dipenuhi, yaitu: 
a) Superemasi aturan hukum;

b) Kedudukan yang sama si mata hukum; dan

c) Terjaminnya HAM dalam undang-undang atau undang-undang dasar.

Adapun ciri-ciri negara hukum menurut Sudargo Gautama dalam Hidayat. E. (2016) antara lain:

a) Terdapat pembatasan oleh hukum mengenai kekuasaan negara terhadap perorangan.

b) Memiliki asas legalitas yang mesti ditaati.

c) terdapat pemisahan kekuasaan, agar asas hak asasi benar benar terlindungi.

Di dalam negara hukum, segala sesuatu baik tindakan maupun penyelenggaraan negara dan warga negaranya harus berlandaskan dan sesuai dengan hukum yang telah berlaku. Negara maupun warga negara harus patuh dan taat terhadap hukum yang telah ditetapkan, yang mana hukum ini sifatnya mengikat dan memaksa, diciptakannya hukum atau ditetapkannya perundang-undangan ini dilakukan untuk menjunjung tinggi hak-hak warga negara yang ada di dalamnya dengan membuat pembatasan-pembatasan tertentu demi menciptakan suatu keadilan di dalam tatanan kehidupan bermasyarakat dan bernegara sesuai dengan tujuan dari hukum itu sendiri, yakni mengaturtata tertib dalam pergaulan hidup masyarakat dengan damai dan adil. Oleh karena itu diwajibkan bagi negara dan setiap warga negara untuk mematuhi hukum yang berlaku demi terciptanya kesejahteraan bersama, karena pada dasarnya hak dan kewajiban merupakan kedua hal yang tidak dapat dipidahkan, adanya suatu hak mesti memenuhi suatu kewajiban terlebih dahulu.

Negara hukum dipandang sebagai negara yang terbaik, karena di dalam negara hukum memiliki tiga inti pokok, yang terdapat di berbagai hukum konstitusi di hampir semua negara hukum yakni perlindunga HAM, Ditetapknanya ketatanegaraan suatu negara dan pembatasan kekuasaan dan wewenang setiap organ-organ negara. Negara (pemerintah) tidak dapat bertindak sewenang-wenang terhadap masyarakat perorangan karena setiap warga negara memiliki hak terhadap negara, yang mana dalam negara hukum semua dibatasi oleh hukum yang mesti ditaati baik bagi pemerintah maupun aparaturnaya. Setiap tindakan negara harus berlandaskan hukum, yang teah ditetapkan sebelumnya. Dan untuk melindungi hak asasi warga negarnnya diadakan pemisahan kekuasaan, pelaksana dan pengadil harus dipiisah oleh badan pembuat peraturan dan perundang undangan agar setap hak asasi terlindungi dengan baik.

\section{HAM DAN UPAYA PENEGAKANNYA}


HAM (hak asasi manusia) adalah seperangkat hak kodrati yang merupakah hak dasar dan telah melekat pada diri seseorang semenjak lahir, sebagai pemberian langsung dari Tuhan yang Maha Esa, yang sudah pasti dimiliki oleh setiap individu tanpa pengecualian, karena HAM bersifat universal. HAM tidak dapat dicabut maupun dirampas melainkan harus dijunjung tinggi dan wajib untuk dihormati, dilindungi oleh setiap orang, negara, pemerintah dan hukum, atas kehormatan dan perlindungan harkat dan martabat manusia. HAM menurut Jan Materson adalah hak-hak yang diwariskan dan melekat dari dalam diri manusia, dan tanpa hak-hak tersebut manusia tidak dapat hidup sebagi manusia. Oleh sebab itu hak asasi manusia ini mutlak dimiliki oleh setiap individu sebagai manusia yang memiliki harkat dan martabat, batas dari HAM yang dimiliki seseorang adalah HAM yang melekat pada diri orang lain (Hidayat, E. 2016).

Rosevelt mengemukakan The Four Freedoms, yang mana dalam pendapatnya tersebut Rosevelt menjelaskan bahwa dalam kehidupan bermasyarakat dan bernegara manusia memiliki empat kebebasan, yaitu:

a) kebebasan dalam berbicara dan mengemukakan pendapat (Freedom of Speech);

b) kebebasan dalam memeluk agama sesuai kepercayaan masing-masing (Freedom of Religie);

c) kebebasan dari rasa takut (Freedom from Fear); dan

d) kebebasan dari kemiskinan atau kemeralatan (Freedom from Want).

Hak asasi manusia adalah seperangkat hak yang pasti dimiliki setiap orang, dimana batas dari HAM itu sendiri adalah HAM yang dimiliki oleh orang lain. HAM wajib dihormati dan dijunung tinggi oleh setiap orang, hukum, pemerintah dan negara, yang dalam pengupayaan perlindungannya dibentuk lah suatu perundang-undangan untuk melindungi hak asasi setiap warga negaranya. Dalam hal perlindungan HAM ini, perlu di tegakkan hukum setegas-tegasnya demi tercapainya sebuah keadilan yang hakiki dan subtantif, dengan pertimbangan kepentingan perlindungan hak asasi setiap warga negara, dan kebijakankebijakan tertentu yang dibuat oleh hakim dalam mengadili seorang pelanggar hak asasi manusia.

Untuk menegakan perlimndungan HAM, di Indonesia sendiri sebagai salah satu negara hukum mengenai hal tersebut telah di buat apengaturan hukum mengenai hak asasi manusia. Yang mana pengaturan hukum ini pada dasarnya telah tercantum di dalam batang tubuh dan 
pembukaan Undang-Undang Dasar 1945, yaitu pada Adapun inti pokok dari pasa-pasal mengenai HAM tersebut antara lain:

a) Pasal 27 (1): Kesamaan kewajiban dan kedudukan dimata hukum dan pemerintahan.

b) Pasal 27 (2): Hak atas pekerjaan dan penghidupan yang layak.

c) Pasal 28: Hak atas kemerdekaan berserikat dan berkumpul.

d) Pasal 29 (2): Hak atas kebebasan dalam memeluk agama dan melaksanakan ibadat.

e) Pasal 31 (1): Hak untuk mendapatkan pengajaran/pendidikan.

Dalam kasus pelanggaran HAM seorang tersangka kasus pelanggaran HAM harus diadili untuk mempertanggung jawabkan kesalahannya di depan pengadilan dan hakim berdasarkan undang-undang yang berlaku, tanpa membeda-bedakan seseorang yang mana pada hakikatnya semua orang sama dimata hukum. Pengaturan hukum mengenai HAM ini bisa disebut sebagai sumber atau dasar dari ditetapkannya hukum-hukum yang berlaku, karena perundang-undangan yang ditetapkan atas pertimbangan perlindungan hak asasi yang dimiliki oleh warga negara. Oleh karena itu sebagian besar pengaturan hukum merujuk kepada perlindungan hak asasi manusia.

Selain penetapan petaturan hukum mengenai HAM, pengupayaan penegakkan HAM di Indonesia juga dilakukan dengan membuat beberapa lembaga-lembaga perlindunagn HAM demi mendukung penegakan dan perlindungan HAM. lembaga ini berfungsi sebagai pembantu dalam hal pelaksanaan ham yang melindungi dan menegaakan hak asasi manusia yang bertujuan untuk menjadikan kepribadian di masyarakat sebagi manusia seutuhnya yang mampu berpartisipasi di dalam bidng-bidang kehidupan. Adapun lembaga-lembaga perlindungan HAM ini antaara lain; Komnas HAM (Komisi Nasional Hak Asasi Manusia, Pengadilan HAM, Komisi Nasional Anti Kekerasan Terhadap Perempuan, Komisi Nasional Perlindungan Anak (KNPA) dan Komisi Perlindungan Anak Indonesia (KPAI), Komisi Kebenaran dan Rekonsiliasi, dan LSM Pro Demokrasi dan HAM.

Dengan disusunya pengaturan hukum dan juga alat pendukung perlindungan HAM lainnya, diharapkan masyarakat bisa lebih menyadari lagi betapa pentingnya HAM dalam kodratnya sebagai manusia, oleh karena itu perlindungan ham ini sangat diperlukan terutama dalam konteks negara hukum yang mana telah menjadi salah satu ciri dan juga kewajiban bagi negara hukum untuk melindungi segenap hak yang teah melekat pada diri manusia sebagai anugerah tadi Tuhan Yang Maha Esa. 
Kesadaran akan pentingnya HAM sangatlah penting untuk membangun karakter bangsa yang peduli terhadap hak asasi orang lain dan tentunya patuh terhadap hukum. Upaya penegakan dan pembangunan kesadaran akan HAM ini dapat dibangun sejak dibangku sekolah dengan melakukan beberapa penanaman karakter dan nilai-nilai terhadap peserta didik untuk kesadaran dan pelaksanaan HAM yang baik kedepannya. Adapun fungsi dari penanaman pendidikann karakter ini adalah untuk menumbuh kembangkan kemampuan dasar peserta didik agar berpikir cerdas, berperilaku yang berakhlak, bermoral, dan melakukan sesuatu yang baik lagi bermanfaat bagi diri sendiri, keluarga dan masyarakat (Putra, M. A. H. 2019). Oleh karena itu, dengan adanya pendidikan karakter kepada peserta didik, diharapkan ia dapat menanamkan suatu karakter yang membuat peserta didik paham akan keberadaan HAM dan pentingnya HAM dalam kehidupan bermasyarakat dan bernegara.

\section{PERLINDUNGAN HAM DALAM KONTEKS NEGARA HUKUM}

Sebagai negara hukum, negara memiliki suatu kewajiban di dalam melindungi hak asasi manusia warga negaranya. Yang mana salah satu ciri yang melekat di dalam negara hukum adalah terjaminnya perlindunagn hak asasi manusia yang telah tercantun di dalam ideologi negara maupun hukum nasional. Negara hukum dapat dikatakan sebahai tempat dimana HAM ini diakui secara sepenuhnya dan segenap jiwa dijunjung tinggi oleh negara. Dimana negara hukum meletakkan posisi HAM sebagai harkat dan martabat manusia yang tidak dapat diambil maupun dirampas, melainkan harus, dihormati, diakui dan dilindungi baik dalam presepsi hukum, negara, pemerintah, maupun sesama manusia. Hal ini dapat dilihat dari penyusunan perundang-undangan menenai Hak Asasi Manusia, pembuatan konstitusi-konstitusi, lembagalembaga yang membantu dalam hal perlindungan hak asasi manusia, selain itu hak asasi manusia dalam negara hukum juga termaktubkan di dalam konstitusi negara dan menjadikannya sebagai hukum nasional.

Negara-negara di dunia sebagian besarnya telah mengakui dan menghormati keberadaan HAM. Tetapi masih banyak negara yang masih menutup mata mengenai pentingnya penegakkan dan perlindungan HAM, sehingga masih banyak terjadi pelanggaranpelanggaran hak asasi manusia. Seperti halnya pada negara Amerika Serikat yang dikritik keras oleh HRW (Human Rights Watch) yang merupakan organisasi HAM yang terkemuka, mereka mengeluarkan laporan atas pelanggaran HAM yang dilakukan Amerika Serikat di berbagai bidang, seperti halnya dalam masalah perbedaan rasial, pembunuhan yang dilakukan oknum polisi kepada salah satu rakyat berkulit hitam, masalah penahanan dan pengadilan kejahatan 
yang mana Amerika menjadi penduduk terbesar di dunia yang dilaporkan melakukan penahanan, mencapai 2,37 juta orang (Aswandi, 2019).

Kasus pelanggaran terhadap HAM harus diminimalisir semaksimal mungkin, untuk meningkatkan kesejahteraan masyarakat dan menjunjung tinggi harkat dan martabat seluruh masyarakat sebagai manusia yang utuh. Upaya-upaya yang dapat dilakukan dalam meminimalisir kasuus-kasus pelanggaran ham, terutama pada negara hukum adalah melakukan penegakkan pengaturah hukum mengenai hak asasi semaksimal mungkin, dimana tentunya sudah menjadi kewajiban utama bagi negara hukum untuk melindungi dan menjunjung tinggi hak asasi yang dimiliki oleh setiap warganya. Merlalui pengaturan hukum yang tegas yang sifatnya mengikat, diharapkan hukum yang berkalu dapat menekan perilaku manusia yang berbuat sewenang-wenang terhadap orang lain, sehingga hak asasi yang menjadi harkat dan martabat manusia ini tetap terjaga dan kedamaian terjadi di dalam kehidupan bermasyarakat dan bernegara.

Di indonesia sendiri sebagai salah satu negara hukum di dunia, HAM begitu diperhatikan dan dijunjung tinnggi, hal ini dapat terlihat dari ditemukannya peraturaan mengenai hak asasi manusia di dalam hukum dasar dan perundang-undangan negera indonesia yakni dalam pembukaan UUD 1945 dan batang tubuh UUD 1945 (sebelum amandemen), terutama dalam pasal 27 ayat 1 dan 2, pasal 29 ayat 2, pasal 30 dan 31 ayat 1, dan UndangUndang No.39 tahun 1999 tentang Hak Asasi Manusia. Sedangkan di dalam Undang-Undang Republik Indonesia 1945 sesudah amandemen, mengenai hak asasi manusia tercantum di dalam pasal 28 a sampai dengan pasasl 28 j, dan untuk lebih memperkuat hukum mengenai HAM ini pemerintah mengambil keputusan dengan mengesahkan Ketetapan Nomor XVII/MPR/1998 mengenai HAM yang meliputi hak hidup, hak untuk berkeluarga dan memiliki keturunan, hak keadilan, hak memperoleh kemerdekaan, hak dalam pengembangan diri, hak kesejahteraan, hak mendapatkan perlindungan dan pemajuan, hak keamanan dan hak dalam kebebasan informasi.

Pada dasarnya aturan hukum ada dan ditetapkan agar seseorang itu tidak berbuat sewenang-wenang terhadap orang lain, hukum ini fungsinya untuk membatasi suatu perilaku yang akan merugikan seseorng. Tujuan dari disusunnya sebuah pengaturan hukum mengenai perlindungan HAM ini bukan hanya sekedar menuju suatu keadilan, melainkan ketertiban agar masyarakat yang berada dalam lingkungan tempat tinggalnya merasa aman dan damai. Pengaturan hukum mengenai HAM ini ditujukan untuk meningkatkan dan mempertahankan 
harkat dan martabat manusia, karena hak asasi merupakan hal yang begitu penting bagi manusia itu sendiri tanpa hak tersebut seseorang akan kehilangan harkat dan martabatnya sebagai manusia seutuhnya.

\section{SIMPULAN}

HAM (hak asasi manusia) adalah seperangkat hak kodrati yang merupakah hak dasar dan telah melekat pada diri seseorang semenjak lahir, sebagai pemberian langsung dari Tuhan yang Maha Esa, yang sudah pasti dimiliki oleh setiap individu tanpa pengecualian, karena HAM bersifat universal. HAM tidak dapat dicabut maupun dirampas melainkan harus dijunjung tinggi dan wajib untuk dihormati, dilindungi oleh setiap orang, negara, pemerintah dan hukum, atas kehormatan dan perlindungan harkat dan martabat manusia. Sebagai negara hukum, negara memiliki suatu kewajiban di dalam melindungi hak asasi manusia warga negaranya. Yang mana salah satu ciri yang melekat di dalam negara hukum adalah terjaminnya perlindunagn hak asasi manusia yang telah tercantun di dalam ideologi negara maupun hukum nasional.

Negara-negara di dunia sebagian besarnya telah mengakui dan menghormati keberadaan HAM. Di indonesia sendiri sebagai salah satu negara hukum, HAM begitu diperhatikan dan dijunjung tinnggi, hal ini dapat terlihat dari peraturaan mengenai hak asasi manusia di dalam hukum dasar dan perundang-undangan negera indonesia yakni dalam pembukaan UUD 1945 dan batang tubuh UUD 1945 (sebelum amandemen), dalam pasal 27 ayat 1 dan 2, pasal 29 ayat 2, pasal 30 dan 31 ayat 1, dan Undang-Undang No.39 tahun 1999 tentang Hak Asasi Manusia. Sedangkan di dalam Undang-Undang Republik Indonesia 1945 sesudah amandemen, mengenai hak asasi manusia tercantum di dalam pasal 28 a sampai dengan pasasl 28 j, dan juga Ketetapan Nomor XVII/MPR/1998. Selain itu pengupayaan penegakkan HAM di Indonesia juga dilakukan dengan membuat beberapa lembaga-lembaga perlindunagn HAM demi mendukung penegakan dan perlindungan HAM.

\section{REFERENSI}

Anshar, S. (2019). Konsep Negara Hukum dalam Perspektif Hukum Islam. Soumatera Law Review, 2(2), 235-245. 
Aswandi, B., \& Roisah, K. (2019). Negara Hukum Dan Demokrasi Pancasila Dalam Kaitannya Dengan Hak Asasi Manusia (HAM). Jurnal Pembangunan Hukum Indonesia, 1(1), 128-145.

Ediwarman, H. (2000). Perlindungan HAM Dalam Proses Peradilan (the Human Rights Protection in the Process of Justice). Indonesian Journal of Criminology, 1(1), 4230.

Hidayat, E. (2016). Perlindungan hak asasi manusia dalam negara hukum indonesia. $A S A S, 8(2)$.

Kusniati, R. (2011). Sejarah Perlindungan Hak Hak Asasi Manusia dalam Kaitannya dengan Konsepsi Negara Hukum. INOVATIF Jurnal Ilmu Hukum, 4(5).

Putra, M. A. H. (2019). Building Character Education Through The Civilization Nations Children. The Kalimantan Social Studies Journal, 1(1), 12-17.

Rosviyana, P. M., \& Sukranatha, A. A. K. (2019). PENEGAKAN HUKUM TERHADAP TERSANGKA PENGEDAR NARKOBA DI FILIPINA DITINJAU DARI PERSEPEKTIF HAM INTERNASIONAL. Kertha Negara: Journal Ilmu Hukum, 7(9), 1-14.

Supriyanto, B. H. (2016). Penegakan Hukum Mengenai Hak Asasi Manusia (HAM) Menurut Hukum Positif di Indonesia. Jurnal Al-Azhar Indonesia Seri Pranata Sosial, 2(3), 151168.

Triwahyuningsih, S. (2018). Perlindungan dan Penegakan Hak Asasi Manusia (HAM) di Indonesia. Legal Standing: Jurnal Ilmu Hukum, 2(2), 113-12.

Wahab, A. A. [et. al.]. (2014). Konsep Dasar IPS. Tanggerang Selatan: Universitas Terbuka. 